\title{
When Does Economic Freedom Promote Well Being? On the Moderating Role of Long-Term Orientation
}

\author{
Johan Graafland ${ }^{1}[D$ \\ Accepted: 22 November 2019 / Published online: 30 November 2019 \\ (C) The Author(s) 2019
}

\begin{abstract}
An increasing volume of literature has shown that economic freedom is related to life satisfaction. However, life satisfaction may not fully describe well-being because of its subjective nature. This study contributes to previous literature by extending analysis of the relationship between economic freedom and life satisfaction to other dimensions of wellbeing as measured by the better life index of the OECD that includes both objective and subjective measures. A second innovation of this paper is that, in explaining the differences in well-being between countries, we conjecture that the relationship between free market institutions as measured by economic freedom and well-being is moderated by the cultural dimension of long-term orientation. This hypothesis is supported for six out of 11 dimensions of well-being: income, community, health, life satisfaction, safety, and work-life balance. Our study shows that looking at interdependencies between culture and formal institutions can increase the explanatory power of internationally comparative research into well-being.
\end{abstract}

Keywords Economic freedom $\cdot$ Long-term orientation $\cdot$ Moderation $\cdot$ OECD better life index $\cdot$ Well-being

\section{Introduction}

A growing number of studies have been carried out into the relationship between economic freedom and human well-being. The concept of economic freedom relates to the degree of personal choice, voluntary exchange, freedom of competition, and protection of privately-owned property afforded by society (Gwartney et al. 2017). The concept has been analyzed in more than 400 scientific articles (Hall and Lawson 2014). Previous research has shown that economic freedom is positively related to income per capita or economic growth (De Haan et al. 2006; Justesen 2008; Faria et al. 2016; Murphy 2016; Bennett et al. 2017; Murphy and O’Reilly 2018; Spruk and Kešeljević 2018). Other studies have shown

Johan Graafland

j.j.graafland@uvt.nl

1 Department of Economics/Department of Philosophy, CentER/Tilburg Sustainability Center, Tilburg University, P.O. Box 90153, 5000 LE Tilburg, The Netherlands 
that economic freedom also correlates with life satisfaction (Veenhoven 2000; Ovaska and Takashima 2006; Gropper et al. 2011; Graafland and Compen 2015).

Income per capita and life satisfaction, however, are both imperfect indicators of the broader concept of well-being that includes the full range of factors influencing what human beings value in life (Stiglitz et al. 2009). For example, GDP per capita does not represent all the benefits of economic activity in a country, it merely represents an estimate of the costs (Van den Berg 2009). Life satisfaction may not capture all relevant dimensions of well-being, as it does not reflect objective indicators of long-term conditions for wellbeing, such as physical capital, human capital, environmental capital (i.e. natural resources, biodiversity, climate), and social capital. Drawing upon recommendations made by Stiglitz et al. (2009), the OECD constructed a so-called "Better Life Index" (BLI) which complements income and life satisfaction with nine other dimensions of well-being: housing, jobs, community, education, civic engagement, environment, health, work-life balance, and safety (Mizobuchi 2014; Durand 2015; Peiró-Palomino and Picazo-Tadeo 2018; Balestra et al. 2018).

To date, only one exploratory study by Nikolaev (2014) has investigated the relationship between economic freedom and the Better Life Index of the OECD. Nikolaev (2014) used data from OECD Better Life Index to estimate the relationship between economic freedom and well-being over one period (2010) and found a positive relationship for most aspects of well-being. The relationship between economic freedom and well-being is, however, complex and likely to depend on other societal characteristics as well. In this paper we argue that the relationship between economic freedom and well-being is contingent on the culture of the society. More specifically, we contend that cultural orientations with regard to the time dimension are likely to moderate the relationship between economic freedom and well-being. Market parties will use the freedom of choice that economic institutions provide them in a beneficial way only if they are prepared to make investments that pay off in the long term. In free societies with cultures emphasizing a focus on short-term results, individuals and companies are more likely to refrain from making this type of investment. The longer their time orientation, the more market parties will value the long-term consequences of those economic decisions that benefit the well-being in society. The central research questions that we focus on in this paper are therefore: (1) How is economic freedom related to well-being? (2) How does long term orientation moderate the relationship between economic freedom and well-being?

This paper contributes to literature in two important ways. First, our paper provides an important theoretical contribution by conjecturing that the relationship between economic freedom and well-being is contingent on the cultural characteristic of long-term orientation, such that economic freedom will only correlate positively with well-being for countries characterized by a long-term orientation. Second, our paper presents an empirical analysis of the relationship between economic freedom, long-term orientation and wellbeing. Previous explorative research by Nikolaev (2014) used simple bivariate correlation analysis and only controlled for the level of personal income. In order to increase the reliability of the analysis, we increased the number of observations by extending the sample period from 1 to 7 years and controlled for a larger set of relevant control variables. Furthermore, in contrast to Nikolaev (2014), we test whether the relationship between economic freedom and well-being is contingent on long-term orientation.

In what follows, we first present a review of the literature on the relationships between economic freedom and well-being, and between long-term orientation and well-being. Section 3 presents the theoretical set up of our study and introduces the novel hypothesis that the strength of the relationship between well-being and economic freedom is dependent on 
long-term orientation. Section 4 discusses data sources and econometric methodology of the research. Section 5 reports the findings of the regression analysis. In the last section, we summarize our findings.

\section{Literature Review}

Most research on the relationship between economic institutions and quality of life has focused on GDP per capita. GDP per capita provides relevant information about quality of life. Improved living standards not only provide a direct indication of material dimensions of well being, but they are also an important pre-condition for other types of well being, including health and leisure (see below), life satisfaction (Di Tella et al. 2003), and existential security that stimulates self-expression values and freedom (Inglehart et al. 2008). Self-expression might, in turn, contribute to democratization, growing support for gender equality, and growing acceptance of outgroups. All of these are closely linked to happiness. Indeed, Adam Smith already recognized that commercial society increases human happiness by allowing for a greater degree of personal liberty and security than pre-commercial societies were able to provide, rather than by increasing richness (Rasmussen 2006). As Smith stated: "Commerce and manufactures gradually introduced order and good government, and with them, the liberty and security of individuals. This, though it has been the least observed, is by far the most important of all their effects." (Smith 1776: III. iv.4).

Still, literature has argued that GDP per capita has also several shortcomings in terms of serving as a proxy for well-being. For example, high income does not guarantee respect of human freedom rights (Bennett et al. 2016). Furthermore, Stiglitz et al. (2009) argue that per capita GDP does not track changes in the quality of products, does not take account of depreciation of capital and the degradation in quality of the natural environment (due to negative externalities), has difficulties in measuring the quality of government-provided services, does not isolate defensive consumption that has no direct benefit, and is only related to wealth in the long term (dependent on the savings ratio). Furthermore, GDP per capita does not capture non-market household production, informal economic activity, leisure, and other non-material aspects of quality of life.

Some of the limitations of GDP per capita as an indicator of well-being are reduced by using subjective well-being. The greatest strength of subjective well-being measures is their simplicity: relying on people's own judgments is a convenient shortcut and potentially provides a natural way to aggregate various experiences in a manner that reflects people's satisfaction with their own preferences. However, subjective well-being measures lack a more objective estimation of well-being dimensions. If the subjective valuation is based on irrational considerations (e.g. types of preference satisfaction that harm the individual's happiness), its usefulness as measurement of well-being diminishes. Other weaknesses are that life satisfaction reports can be influenced by situational factors, may be dependent on temperament, or influenced by social expectations. Finally, the importance of subjective well-being as an attribute of the good life may vary across individuals and nations (Diener and Suh 1997).

The subjective well-being approach should therefore be complemented by the capability approach that gives prominence to people's objective conditions and the opportunities available to them (Sen 1984; Nusbaum 2011). Objective features that are considered to be important are, for example, health, education, social connections, environmental conditions, and safety (Stiglitz et al. 2009). The OECD better life index is a recent holistic 
approach to measuring these dimensions of well-being across different countries (Durand 2015; Peiró-Palomino and Picazo-Tadeo 2018; Balestra et al. 2018). This multidimensional index combines income and life satisfaction with nine other dimensions of well-being, including housing, jobs and earnings, community, education, environment, civic engagement, health, safety, and work-life balance. ${ }^{1}$

In the remainder of this section we will first discuss the literature on the relationship between economic freedom and different dimensions of well-being measured by the OECD Better Life Index. Then we summarize literature on the relationship between long-term orientation and these various dimensions of well-being.

\subsection{Well-Being and Economic Freedom}

An important characteristic of national institutions is the extent to which they promote economic activity as coordinated by "personal choice, voluntary exchange, open markets, and clearly defined and enforced property rights", or in other words, economic freedom (Gwartney 2009: 939). Organizations such as the Fraser Institute annually publish indexes of economic freedom, distinguishing aspects such as low government spending, protection of property rights, sound money, free trade, and low regulatory stringency. Various studies have argued that free markets and competition stimulate income per capita or economic growth and have found a positive relationship (De Haan et al. 2006; Justesen 2008; Graafland and Compen 2015; Faria et al. 2016; Murphy 2016; Bennett et al. 2017; Murphy and O’Reilly 2018; Spruk and Kešeljević 2018). Other studies have argued that economic freedom stimulates life satisfaction and have shown that a positive relationship exists between them (Veenhoven 2000; Ovaska and Takashima 2006; Gropper et al. 2011; Gehring 2013; Graafland and Compen 2015) as well as with (several dimensions of) emotional well being (Nikolaev and Bennett 2017).

Economic freedom may also have a favorable effect on other dimensions of well-being. Nikolaev (2014) analyzed the relationship between economic freedom and all the subdimensions of well-being distinguished in the Better Life Index for 34 OECD countries and found a positive correlation for almost all aspects. These results tended to be consistent across genders and income classes, although some differences were found.

These findings are supported by studies that have addressed the influence of economic freedom on one of the dimensions of well-being (other than income per capita and life satisfaction mentioned above). ${ }^{2}$ First, Campbell et al. (2008) found that economic freedom is positively related to housing values. They hypothesized that economic freedom improves a state's well-being and it therefore becomes a more attractive place to live. In turn, this causes an increase in the value of houses. Using the Housing Price Index (HPI) to measure changes in the value of single-family homes, they found that states with small government size and liberalized labor markets experience more rapid housing value appreciation.

Furthermore, as economic freedom has been found to increase income, and income has been shown to correlate with health (Benzeval and Judge 2001; Frijters et al. 2005), it is not surprising that some studies have found economic freedom is also positively related

\footnotetext{
1 See https://stats.oecd.org/index.aspx?DataSetCode=BLI for a detailed description of the underlying indicators of the Better Life Index.

${ }^{2}$ For a literature overview of studies showing a positive relationship between sub dimensions of economic freedom and well-being, see Appendix 1.
} 
to better health. Stroup (2007) has argued that the increase in market place effectiveness due to economic freedom will not only lead to greater prosperity, but also to choices by individuals that enable them to live longer, healthier lives. Using panel data analysis on a sample of 104 countries during five periods of time (1980, 1985, 1990, 1995, and 2000), he found that economic freedom and health are positively related. A recent study by Hall and Lawson (2014) found, however, that more economic freedom is associated with worse selfreported health status (while reducing health disparities between white and black people). Still, they also found that self-reported health is positively related to income, which might indicate that economic freedom has an indirect positive effect on health.

Other studies have argued that economic freedom may also encourage education (Schofer and Meyer 2005; Stroup 2007). Using data on 109 countries from 1972 to 2011, Feldmann (2017) found a positive relationship between economic freedom and human capital investment. Secure property rights, a low level of taxation and monetary stability protect economic agents from expropriation and create an incentive to invest in human capital. They also enhance the gains from economic exchange, incentivizing individuals to maximize the return on their human capital. Furthermore, economic freedom may stimulate investment in education by facilitating the operation of credit markets. Positive relationships between economic freedom and education were also found by Aixalá and Fabro (2009) and King et al. (2012). Through education, economic freedom may also raise civic participation. Milligan et al. (2004) found that education is positively linked to the quantity as well as to the quality of citizens' involvement in the electoral process. OECD (2000) likewise found that educated people show more active political participation.

Economic freedom has also been found to be positively related to environmental quality: both Baughn et al. (2007) and Hartmann and Uhlenbruck (2015) found a positive link between economic freedom and the corporate environmental responsibility of companies. The reason could be that economic freedom stimulates entrepreneurial solutions to problems such as global warming and environmental protection. Protection of property rights encourages companies to make future-oriented investments in environmental performance, as there is more certainty that they will benefit from the returns to these investments. Better protection of property rights also implies that there is less scope for harming others' interests by pollution (Stroup 2003) which may help overcome the tragedy of the commons. Furthermore, in societies with low levels of economic freedom, people and companies may perceive that the government is in charge of social welfare and define their own environmental responsibilities very narrowly. Stroup (2003) found, however, that economic freedom is only negatively related to air pollution levels (i.e. sulfur oxides, oxides of nitrogen, visible particulates, and carbon dioxide) per dollar of GDP when a country has relatively low level of economic freedom. This would indicate that economic freedom and the environmental quality of a country are unrelated for countries with high economic freedom.

Whereas the explorative research by Nikolaev (2014) indicated a positive relationship between economic freedom and well-being as measured by the OECD Better Life Index, his findings seem to identify one exception, namely work-life balance. Indeed, whereas free markets foster industry, entrepreneurship, and the intrinsic motivation to work (Kreps 1997; Maitland 1997), the downside of the work incentives of free market economies might be that markets encourage a commitment to working that distorts private life. Research by Reynolds and Renzulli (2005) has shown, for example, that entrepreneurship causes considerable interference between private life and work. Block et al. (2018) also found that entrepreneurs experience a poorer work-life balance, since being one's 
own boss makes one work harder than salaried employment (McCloskey 2006). ${ }^{3}$ Furthermore, due to competition, firms have a strong interest in their employees working long hours in order to get as much as possible from them (Schor 1993). As a result, people may find themselves working many hours per week at the expense of other important commitments in their lives, such as family relationships, for a financial reward that, if they thought about it, they might realize they do not really need. Free trade (one of the dimensions of economic freedom) can also distort work-life balance. Due to constant organizational changes in response to the dynamics of the world market, individuals feel more pressure and experience more demanding working practices (White et al. 2003; Lewis 2003; Guest 2002). However, there are also arguments to expect a positive relationship between economic freedom and work-life balance. Economic freedom enables people to enjoy more leisure, because of an increase in income. Most leisure activities require purchasing power to finance the costs incurred by these activities, such as equipment, membership fees, travel cost and the like. People with more purchasing power are better able to afford these costs. As economic freedom increases income per capita, it might therefore encourage more leisure and time for personal care. This is supported by empirical research by Ruseski and Maresova (2014) that shows participation in sports to increase with economic freedom (as well as to decline with hours worked and full-time employment status). They explain this relationship by pointing out that countries with high economic freedom have more marketdriven economies that supply more of the facilities, equipment, and instruction required for individuals to be physically active.

Finally, as economic freedom is positively correlated with individualism, it might also be negatively related to community. Economic freedom assumes personal autonomy (i.e. a state of individual freedom from external authority) and self-reliance (i.e. individuals are solely responsible for their own well-being) and has a close kinship to classical liberalism and liberalism (Bozeman 2007). For instance, Nikolaev and Bennett (2016) found that economic freedom foster perceptions of control (particular the dimension of sound money). ${ }^{4}$ Furthermore, Arikan (2011) found that low government spending correlates with national individualism. Mayda and Rodrik (2005) report that people's preferences with regard to freer trade are negatively related to values concerning neighborhood attachment. However, the empirical evidence is ambiguous, as the correlation analysis between economic freedom and the community dimension of the Better Life Index of the OECD by Nikolaev (2014) showed a positive relationship. A possible explanation is that higher internal locus of control tend to make people more socially active (Nikolaev and Bennett 2016). Furthermore, it is well known that economic freedom increases generalized trust (Graafland and Compen 2015), which may also encourage people to participate in community life. We therefore conclude that the relationship between economic freedom and community is theoretically ambiguous.

\footnotetext{
3 Another well-known finding in literature is that entrepreneurship increases life satisfaction (Benz and Frey 2008). These findings are not necessarily contradicting research on the relationship between entrepreneurship and work-life balance, as entrepreneurship may affect life satisfaction for other reasons than work-life balance. For example, they enjoy more freedom of choice that can enable them to derive more meaning from their work by engaging in purposeful activities through self-directed tasks (Wiklund et al. 2019). This nicely illustrates that the different dimensions of the Better Life Index are heterogeneous and need not correlate (perfectly).

4 Piklit and Rode (2016) identified that particularly life control of lower income groups benefits from more economic freedom.
} 


\subsection{Long-Term Orientation and Well-Being}

Well-being is not only likely to depend on regulative institutions, but (among other factors) also on culture. As culture is a very broad concept, we focus on one specific element of culture, namely long-term orientation.

Long-term or future orientation can be defined as "the degree to which individuals in organizations or societies engage in future-oriented behaviors such as planning, investing in the future, and delaying individual or collective gratification" (House et al. 2004: p. 12). Long-term orientation is related to various types of virtues, such as self-command, temperance, patience, perseverance, and foresight (prudence). People living in countries that are not long-term oriented like to enjoy the moment, but might be incapable of seeing the incompatibility of their current behavior with their long-term goals. In contrast, long-term oriented people have a strong capacity for maintaining self-control and prepare for the future in order to reach their long-term goals, for example by putting more effort in working now to advance their career and long-term economic prosperity, so that they can enjoy more consumption and leisure in the future. Long-term orientation is likely to encourage saving and technological development (Chen 2013; Galor and Ozak 2016) and is therefore likely to be related to higher levels of long-term economic prosperity. Bukowski and Rudnicki (2018) have shown that long-term orientation is a strong cultural predictor of the intensity of national innovation. The rise in savings and economic prosperity will lead to improved quality of housing and an increase in the number of jobs created.

Long-term orientation has also been linked to non-material aspects of the human condition (House et al. 2004), such as health and education. As long-term oriented people are able to delay gratification and able to plan for the future, they are also more likely to invest in their (psychological) health and education that create more favorable future prospects. Chen (2013) found a positive relationship between health and language structures that associate the future and the present (an indicator of long-term orientation). Figlio et al. (2016) estimated that students from countries with long-term oriented attitudes perform better than students from cultures that do not emphasize the importance of delayed gratification. Moreover, parents from long-term oriented cultures are more likely to secure better educational opportunities for their children. As discussed above, higher levels of education encourage civic participation. Through the effects on education, health, income and jobs, long-term orientation will also positively affect life satisfaction. Furthermore, long-term orientation will help people to maintain a proper work-life balance. People that lack sufficient work-life balance (work-life balance is a heterogeneous concept that likely differs across individuals) may suffer from negative consequences for their well being, and these consequences are likely to become more pressing and manifest in the long run. Long-term orientated people will be more able to anticipate and take more account of the negative long-term consequences of an improper work-life balance and adjust their behavior accordingly.

Literature has also argued that a long-time horizon will foster the implementation of environmental policies by companies. The reason is that environmental investments cost money in the short-term (Brammer and Millington 2008), whereas the benefits from engaging in environmental responsibility are mainly realized in the long run (Mallin et al. 2013; Rehbein et al. 2013). Developing business opportunities to meet consumers' increasing demand for environmentally friendly products often takes a long time (Dijk et al. 2013). Hence, the benefits from such investments in lowering production 
costs and augmenting the environmental quality of products mainly exist in the future. A company with an excessive focus on short-term results will reckon with a lower net discounted value from investments in environmental improvements than a company that takes account of long-term results, and will therefore be less inclined to invest in such measures.

Finally, long-term orientation is also likely to improve health and safety, since it encourages people and business to focus on long-term gains and creates more awareness of the importance of a safety culture in companies. Empirical research by Reader et al. (2015) and Keiser (2017) supported this positive relationship.

\section{Conceptual Framework}

In the previous sections, we discussed two strands of literature that have argued that economic freedom and long-term orientation positively affect various dimensions of wellbeing. However, none of these studies has considered that the effects of economic freedom and long-term orientation on well-being may be interdependent. In this section, we will argue that the relationship between economic freedom and well-being is likely to be moderated by long-term orientation. Moderated models explain when a given relationship occurs by explicating that its strength depends on the level of some other (moderating) variables (Preacher et al. 2007). After describing this novel hypothesis, we present the full set of hypotheses and the model that we will test in the empirical analysis.

\subsection{Moderation of the Relationship Between Economic Freedom and Well-Being by Long-Term Orientation}

The intuition of the moderation argument is that economic freedom is not a sufficient condition for stimulating behavior that increases well-being, because that also depends on how people make use of their freedom. If people and companies exhibit virtues that stimulate and enable them to engage in future-oriented behaviors such as planning, investing in the future, and delaying individual or collective gratification, they will use the freedom that economic freedom institutions allow them to make investments that stimulate their welfare in the long-term. For organizations this means sacrificing current profit for future development and sustainability, and for people this translates into a propensity to save and invest for the future. Economic freedom without a long-term perspective is less likely to lead to higher levels of well-being that demand long-term investments. Instant gratification limits people in many facets of their well-being, because they lack the motivation to invest in goods and services that only pay off in the long run, such as investment in health, education, housing, and environment.

Moderation also implies that the influence of the moderator on the dependent variable is contingent on the independent variable. The same can be said of long-term orientation and economic freedom. When there is no economic freedom, long-term oriented people will not invest to meet their long-term needs, as the government is assumed to take responsibility for human well-being in society, including education, health and material welfare. Moreover, LTO-oriented people living in countries with low levels of economic freedom may fear that the state will expropriate their property such that they underinvest in satisfying their long-term needs. Hence, whereas under the first set of conditions-economic freedom without long-term orientation-economic actors will be disinclined to engage in 


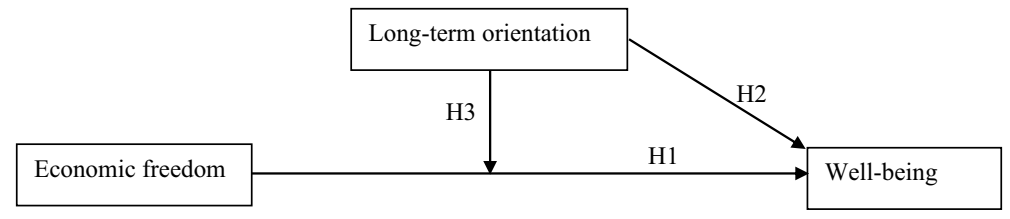

Fig. 1 Conceptual model representing hypotheses for determinants of well-being

practices that will pay out only in the long term, under the second set-long-term orientation without economic freedom-they would perhaps have a stronger inclination to do so, but in practice trust that the government takes responsibility rather than taking personal responsibility for their long-term interests. Based on these arguments, we surmise that the effect of economic freedom on well-being is positively moderated by long-term orientation.

\subsection{Overall Model}

From Sects. 2.1, 2.2 and 3.1, we derive the following set of hypotheses:

H1 Economic freedom is positively related to all dimensions of well-being distinguished in the OECD better life index, except possibly for work-life balance and community.

H2 Long-term orientation is positively related to all dimensions of well-being distinguished in the OECD better life index.

H3 The effect of economic freedom on the various dimensions of well-being distinguished in the OECD better life index is positively moderated by long-term orientation.

The conceptual model is depicted in Fig. 1.

Mathematically, the model can be described by the following equation:

$$
\mathrm{BLI}_{\mathrm{i}, \mathrm{j}, \mathrm{t}}=\alpha_{\mathrm{j}}+\beta_{\mathrm{j}} \mathrm{EF}_{\mathrm{i}, \mathrm{t}}+\gamma_{\mathrm{j}} \mathrm{LTO}_{\mathrm{i}}+\delta_{\mathrm{j}} \mathrm{EF}_{\mathrm{i}, \mathrm{t}} * \mathrm{LTO}_{\mathrm{i}}+\sum \varepsilon_{\mathrm{j}, \mathrm{k}} \mathrm{X}_{\mathrm{i}, \mathrm{k}, \mathrm{t}}+\sum \zeta_{\mathrm{j}, \mathrm{n}} \mathrm{Z}_{\mathrm{i}, \mathrm{n}}
$$

BLI denotes Better Life Index, EF economic freedom, LTO (time-invariant) long-term orientation, $\mathrm{X}(\mathrm{k})$ time variant control variables, and $\mathrm{Z}(\mathrm{n})$ time invariant control variables. The index i denotes country, $\mathrm{j}$ denotes one of the 11 dimensions of the OECD Better Life Index, and tenotes year. Hypothesis 1 is tested by estimating coefficient $\beta$, hypothesis 2 by the estimation of coefficient $\gamma$, and hypothesis 3 by the estimation of coefficient $\delta$. For further clarification of Eq. (1), see the methodology section below.

In the regression analysis, we controlled for a set of control variables used in other cross-country studies. First, following Ovaska and Tashimi (2006) we included political rights, civil liberty, and the female labor participation rate. Other controls suggested in literature, due to their effects on economic activity and well-being, are urbanization, the age structure of the society, and income inequality (Bennet and Nikolaev 2016; Graafland and Lous 2018). Besides these time-variant controls, we added a set of time-invariant control 
variables. Firstly, economic growth theory implies that geographical factors matter (Gwartney et al. 2017). As geographical variables we used the log of great circle air distance to main capital goods providing regions (Mayer and Zignago 2011) ${ }^{5}$ (no) access to sea (landlocked), and average annual temperature as an indicator of climate (Bjørnskov et al. 2008). Second, we included regional dummies for post-communistic countries and Latin America (Hofstede et al. 2010; Acemoglu et al. 2001; Graafland and Compen 2015). Third, a dummy for monarchy is included as it can provide a unifying factor, positively affecting well-being (Bjørnskov et al. 2008). ${ }^{6}$

\section{Methodology}

\subsection{Measurement and Data Sources}

For the measurement of well-being we used the OECD Better Life Index (BLI). The OECD notes that the index scores cannot be compared over time, because the methodology is still being fine-tuned. ${ }^{7}$ The index currently covers all 35 OECD members, plus Brazil, Russia and South Africa. The data is available for the years 2011-2017. For each of the 11 dimensions of well-being, we used normalized values. The summary statistics can be found in Table 1. Although literature has developed several methodologies to further aggregate the eleven sub dimensions of well being into an overall indicator of well being, ${ }^{8}$ we will estimate the model for each sub dimension of well being separately.

Following most literature, we will use the 'Economic Freedom of the World Index' (EFWI) of the Fraser Institute as a measurement of economic freedom (Gwartney et al. 2017). The five areas of economic freedom are composite scores of 24 policy areas, which in turn are constructed from several subcomponents. ${ }^{9}$ In total the index covers 42 variables. The variables are weighted equally and aggregated into an average score that ranges from 1 (least free) to 10 (most free).

Long-term or future orientation has been taken from the GLOBE project that measured long-term orientation for 61 societies (on a scale ranging from 1 to 7 ) through survey measurement (House et al. 2004). The GLOBE methodology distinguishes societal practices ("'as is") from societal values ("should be"). Practices capture the tangible attributes of culture (e.g., current policies and practices), and values reflect the intangible attributes (e.g., cultural norms and values) (Brewer and Venaik 2010). Since we are interested in the effects of long-term orientation, we used GLOBE's practices of long-term orientation. Our choice is validated by a correlation analysis relating GLOBE practices and GLOBE values to three indices of long-term orientation based on language structure, developed by Chen (2013). Chen (2013) found that languages that grammatically associate the future and the

\footnotetext{
5 The specific measure is the Great Circle air distance to the major trading centers: New York, Rotterdam and Tokyo. For this we used the CEPII database and picked the shortest distance to either USA, Japan or the Netherlands.

6 We did not include religion, as it is inextricably linked to culture and might contribute significantly to a country's long-term orientation (House et al. 2004).

7 See https://stats.oecd.org/index.aspx?DataSetCode=BLI.

${ }^{8}$ For an overview of six different weighting methods and their advantages and disadvantages, see OECD (2008), Table 24.

9 A concise description of the five areas can be found in Appendix 2.
} 
Table 1 Complete list of measures, statistical descriptives, and sources

\begin{tabular}{|c|c|c|c|c|c|c|}
\hline & $\mathrm{N}$ & Mean & SD & Min & $\operatorname{Max}$ & Source \\
\hline \multicolumn{7}{|l|}{ Better life index } \\
\hline Housing & 239 & 0.58 & 0.16 & 0 & 0.93 & OECD \\
\hline Income & 242 & 0.37 & 0.22 & 0 & 1 & OECD \\
\hline Jobs & 248 & 0.66 & 0.19 & 0.02 & 0.97 & OECD \\
\hline Community & 254 & 0.69 & 0.23 & 0 & 1 & OECD \\
\hline Education & 253 & 0.64 & 0.19 & 0.04 & 0.95 & OECD \\
\hline Environment & 254 & 0.70 & 0.20 & 0 & 1 & OECD \\
\hline Civic engagement & 253 & 0.51 & 0.17 & 0 & 0.95 & OECD \\
\hline Health & 252 & 0.70 & 0.19 & 0.06 & 0.96 & OECD \\
\hline Life satisfaction & 254 & 0.62 & 0.28 & 0 & 1 & OECD \\
\hline Safety & 254 & 0.80 & 0.20 & 0 & 0.99 & OECD \\
\hline Work-life balance & 226 & 0.69 & 0.19 & 0 & 0.98 & OECD \\
\hline \multicolumn{7}{|c|}{ Economic freedom and long-term orientation } \\
\hline Economic freedom & 259 & 7.45 & 0.50 & 6.15 & 8.47 & Fraser institute \\
\hline Long-term orientation & 210 & 3.91 & 0.49 & 2.88 & 4.73 & GLOBE project \\
\hline \multicolumn{7}{|l|}{ Control variables } \\
\hline Population ages $0-14^{\mathrm{a}}$ & 261 & 17.83 & 4.23 & 12.89 & 30.20 & World Bank \\
\hline Population ages $15-64^{\mathrm{a}}$ & 261 & 66.43 & 2.51 & 60.07 & 73.36 & World Bank \\
\hline Population $65+^{\mathrm{a}}$ & 261 & 15.74 & 4.45 & 4.76 & 27.05 & World Bank \\
\hline Civil liberties & 261 & 53.22 & 8.65 & 15.00 & 60.00 & Freedom house \\
\hline Political rights & 261 & 36.58 & 5.97 & 5.00 & 40.00 & Freedom house \\
\hline Net Gini coefficient & 261 & 32.23 & 7.26 & 24.3 & 60.2 & Solt's database \\
\hline Female labor participation rate ${ }^{b}$ & 261 & 53.28 & 7.21 & 28.32 & 73.17 & World Bank \\
\hline Urban population ${ }^{\mathrm{a}}$ & 261 & 77.85 & 11.42 & 49.63 & 97.93 & World Bank \\
\hline Dummy monarchy & 261 & 0.32 & 0.47 & 0 & 1 & Wikipedia \\
\hline Great circle air distance ${ }^{c}$ & 261 & 7.07 & 1.13 & 4.34 & 9.18 & CEPII database \\
\hline Dummy post-communist & 261 & 0.20 & 0.40 & 0 & 1 & \\
\hline Dummy Latin America & 261 & 0.08 & 0.27 & 0 & 1 & \\
\hline Landlocked & 261 & 0.16 & 0.37 & 0 & 1 & \\
\hline Annual average temperature & 261 & 10.24 & 5.41 & -0.6 & 24.5 & Weatherbase \\
\hline
\end{tabular}

${ }^{\mathrm{a}}$ As a percentage of the total population

${ }^{\mathrm{b}}$ As a percentage of female population $15+$

${ }^{\mathrm{c}} \mathrm{Log}$ distance to the Netherlands, Japan or the US

Table 2 Correlation between alternative measures of long-term orientation

\begin{tabular}{llrllll}
\hline & & 1 & 2 & 3 & 4 & 5 \\
\hline 1 & GLOBE practices & 1 & & & & \\
2 & GLOBE values $^{1}$ & $\mathbf{- 0 . 2 7}$ & 1 & & & \\
3 & Chen (strong FTR) $^{\mathrm{a}}$ & $\mathbf{0 . 6 2}$ & $\mathbf{- 0 . 3 1}$ & 1 & & \\
4 & Chen (verb ratio) $^{\mathrm{a}}$ & $\mathbf{0 . 3 8}$ & $\mathbf{- 0 . 3 2}$ & $\mathbf{0 . 8 9}$ & 1 & \\
5 & Chen (sentence ratio) $^{\mathrm{a}}$ & $\mathbf{0 . 4 2}$ & $\mathbf{- 0 . 3 1}$ & $\mathbf{0 . 9 0}$ & $\mathbf{0 . 9 9}$ & 1 \\
\hline
\end{tabular}

Pearson correlation coefficients; bold $p<0.01$

${ }^{\mathrm{a} C}$ Complement of data presented by Chen (2013), Table B1, p. 728 
present, foster future-oriented behavior. Table 2 shows that future orientation as measured by GLOBE practices correlates more to the three measures for future orientation developed by Chen (2013) than the measures based on GLOBE values.

Matching data of GLOBE's future orientation with the BLI index of the OECD, 30 countries overlap. ${ }^{10}$ For Germany and South Africa, the measure used in this study is a combination of two scores, those of the subgroups East and West Germany and Black and White Africans (weighted by population sizes). For Canada the score is only available for the English-speaking part of the population.

\subsection{Econometric Issues}

Since for most of the variables there is little within-country variation over time, we cannot use standard panel regression analysis with fixed country effects. Also the method employed by Bennett and Nikolaev (2016) to average the observations over the period 2011-2017 cannot be used, because of the low number of countries (30) in our sample. This would suggest we should use pooled cross-country analysis. However, as OECD explicitly mentions on its website that it is not advisable to compare the BLI index over time, as its methodology is still being fine-tuned, we made one adjustment and used multilevel regression analysis instead of pooled cross-country analysis, with year as multilevel variable. A multilevel model allows analysis on the effect of both contextual and unit-specific factors. It is important to take care of contextual factors, as error terms are not independent from context. Observations within one group (in this case year) are more similar than in the other group (Peterson et al. 2012). The multilevel model estimation will be a random intercept model. ${ }^{11}$

Another econometric problem that may bias the results is simultaneity bias, as socioeconomic circumstances may influence a country's adoption of economic freedom institutions (Berggren 1999). Following Bennett and Nikolaev (2017), we used economic freedom indicators that are lagged 5 years to minimize endogeneity, whereas long-term orientation is taken from a source in 2004, thus limiting the risk of reverse causality to a minimum. Yet, we acknowledge that causality cannot be proven and therefore we should be cautious about it in the interpretation of our results and in the conclusions of this article. Still, since previous researches that did test on causality showed that economic freedom causally affects income in a positive way (Faria et al. 2016; Bennett et al. 2017), it is likely that a positive effect reflects causal influence from economic freedom.

\section{Empirical Results}

In this section we present the results of our empirical analysis. First, we report the bivariate correlation coefficients. Then we present the results of the multiple regression analysis.

\footnotetext{
${ }^{10}$ For an overview of the countries included in the sample, see Appendix 3.

11 If we used pooled cross-country analysis instead of multilevel modelling, the results did not change.
} 


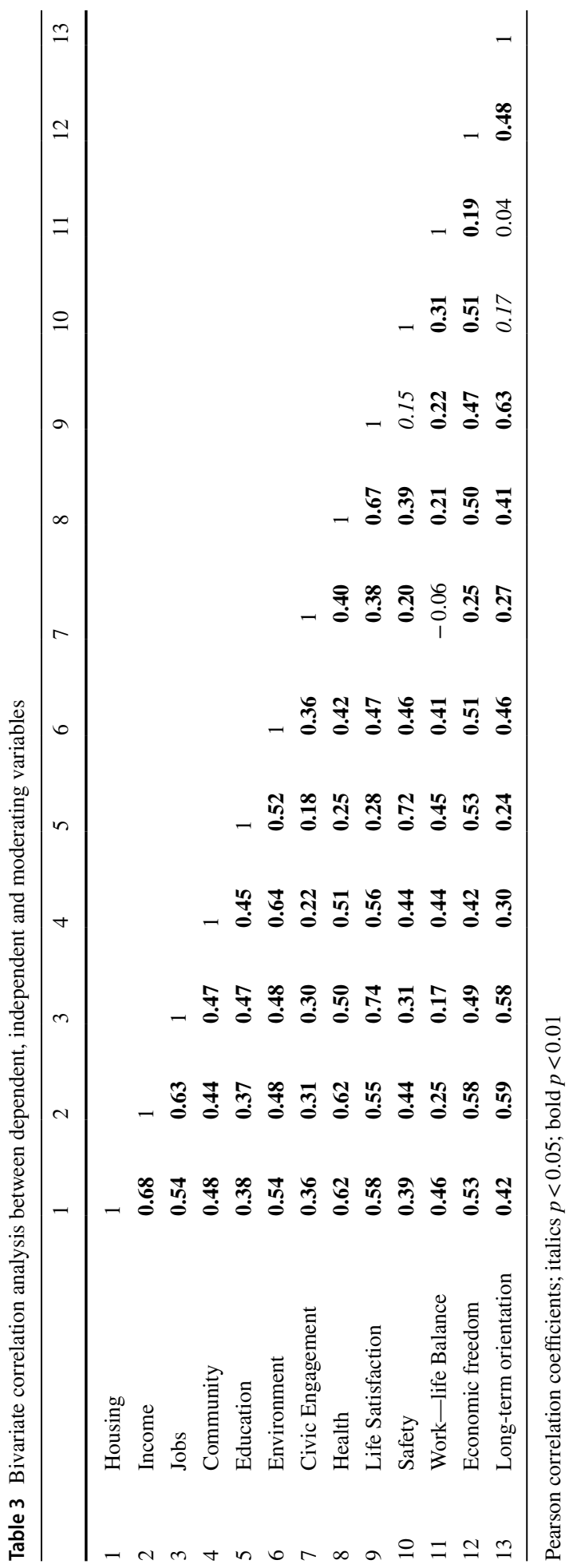




\subsection{Bivariate Correlation Analysis}

Table 3 shows that the main predictors, economic freedom and GLOBE long-term orientation (practices), are significantly and positively related to the BLI scores. Economic freedom is strongly correlated with education, housing, income, safety, and environment and has a relatively small correlation with civic engagement and work-life balance. Longterm orientation is positively correlated with all areas of BLI except work-life balance. The predictor variables are also strongly correlated with each other and the same holds for the BLI indicators, except for the correlation between civic engagement and work-life balance.

\subsection{Multiple Regression Analysis}

In the multiple regression analysis, we report standardized scores of all variables. Standardized coefficients allow for comparison of effect sizes across variables when the variables are measured in different units of measurement by showing the change in the dependent variable in standard deviations caused by a change of the independent variables by one standard deviation. Table 4 reports the results of the multiple regression analysis. We find that economic freedom is significantly and positively related to most indicators of BLI, except community and work-life balance. ${ }^{12}$ These findings support hypothesis $1 .^{13}$ The interaction effect between economic freedom and long-term orientation is significantly positive for income, community, health, life satisfaction, safety, and work-life balance. ${ }^{14}$ Hence, hypothesis 3 is supported for six out of the 11 dimensions of well-being.

It is noticeable that in four out of five cases of insignificant interaction effect (jobs, education, environment and civic engagement), we find a significant positive effect for the linear influence of long-term orientation on the respective well-being indicator, which partly supports hypothesis 2 . Only for housing do we find no significant positive relation with long-term orientation or its interaction with economic freedom.

For the control variables, we find that all have an ambiguous effect on various dimensions of well being. But if significant, civil liberty and female participation rate tend to

\footnotetext{
${ }^{12}$ One reviewer suggested that this may be due to poor measurement of work-life balance. The OECD measures work-life balance by two indicators: (1) The proportion of employees who usually work for pay for more than $50 \mathrm{~h}$ per week. The data exclude self-employed workers who are likely to choose deliberately to work long hours; (2) Data from national time use surveys on the hours devoted to leisure and personal care in a typical day. As the first indicator is a negative indicator, we calculated its normalized value as the complement: $1-$ (country value-min. value in the sample)/(max. value in the sample $-\min$. value in the sample).

${ }^{13}$ In order to test for non-linearities because of the Easterlin paradox (stating that economic development improves subjective well-being only up to a point), we added economic freedom squared as an additional variable (Nikolaev and Bennett 2016). However, for none of the 11 dimensions of the OECD better life index we found support for an inverse $\mathrm{U}$ shaped relationship between economic freedom and better life, except housing. This is in line with the results of Nikolaev and Bennett (2016) who found no evidence for the Easterlin paradox too in their analysis of control perceptions.

${ }^{14}$ If we add two additional dummies for Western European countries and other Western countries, the results do not change, except for work-balance where the interaction term becomes insignificant. A disadvantage of adding more regional dummies is, however, that one then also controls for the cultural differences that we are interested in.
} 


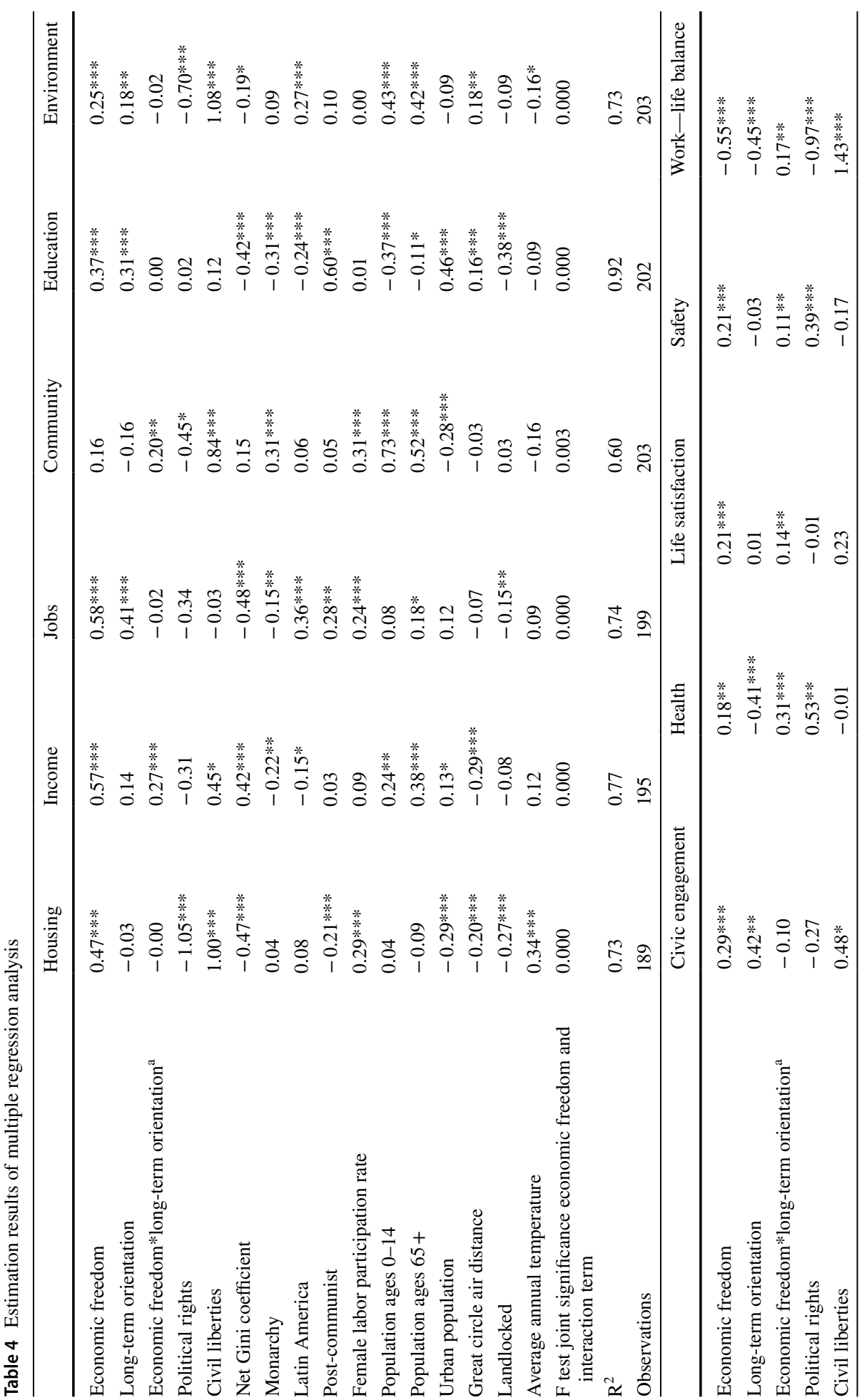




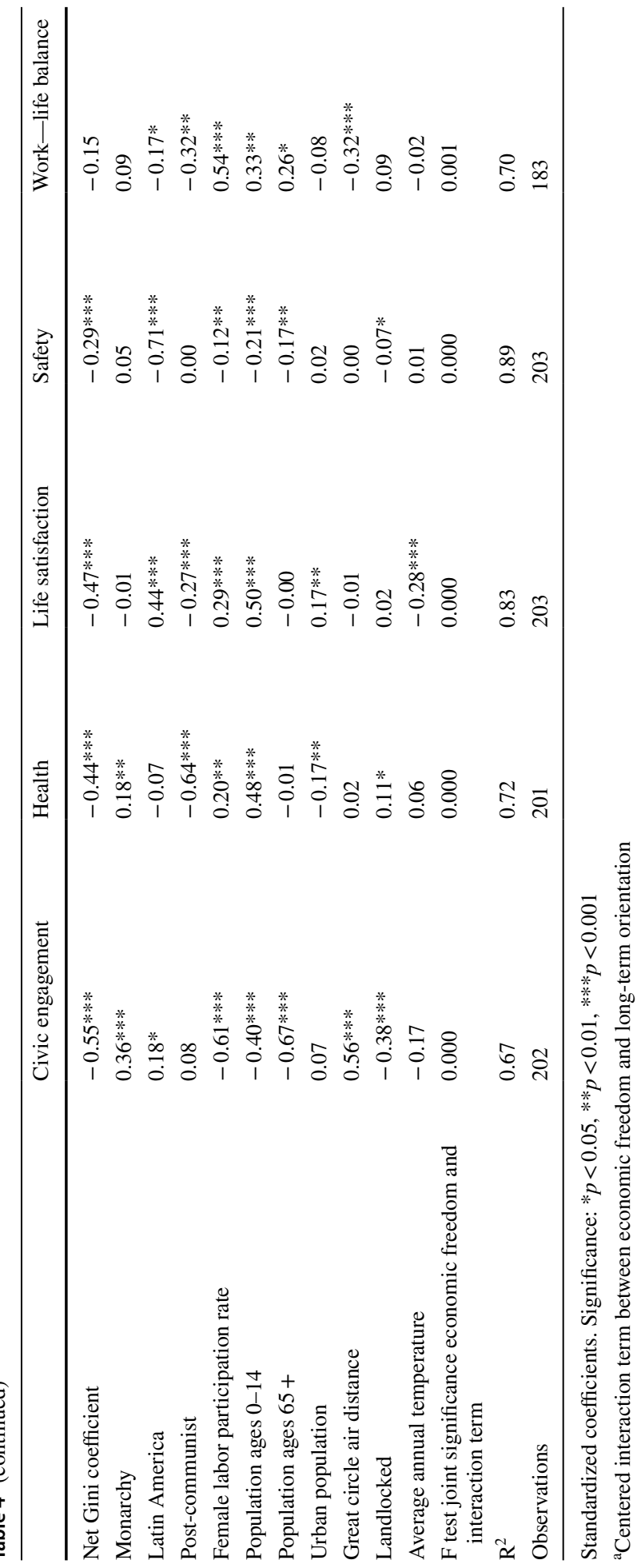


Table 5 Total (standardized) effect of economic freedom on well being

\begin{tabular}{|c|c|c|c|c|c|c|}
\hline Future orientation & Income & Community & Health & Life satisfaction & Safety & Work_life balance \\
\hline Lowest (Russia) & 0.07 & -0.27 & -0.48 & -0.09 & -0.03 & -0.91 \\
\hline $\begin{array}{l}\text { Highest (Switzer- } \\
\text { land) }\end{array}$ & 1.03 & 0.50 & 0.70 & 0.45 & 0.40 & -0.26 \\
\hline $\begin{array}{l}\text { Countries with nega- } \\
\text { tive total effect of } \\
\text { economic freedom }\end{array}$ & None & Russia & $\begin{array}{l}\text { Russia, } \\
\text { Poland, } \\
\text { Hungary }^{\mathrm{a}}\end{array}$ & Russia, Poland & Russia & All \\
\hline
\end{tabular}

${ }^{a}$ Country with the highest future orientation (Switzerland), Plus Czech Republic, Slovenia, Spain, New Zealand, Greece, and Italy

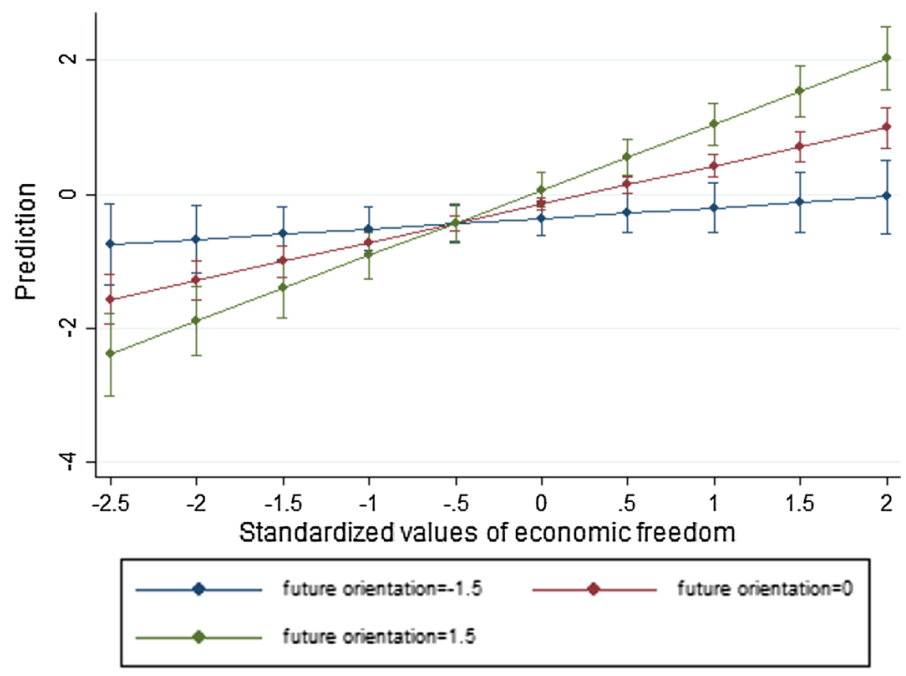

Fig. 2 Standardized effect of economic freedom on income with $95 \%$ confidence interval

have a positive effect on well being, whereas net Gini coefficient and landlocked tend to have a negative effect. ${ }^{15}$

In order to highlight the moderating effect of future orientation, we next calculated for the countries with lowest (Russia) and highest future orientation (Switzerland) the total standardized effects of economic freedom on those dimensions of well being for which we found a significant effect of the interaction term. Table 5 shows that a rise in economic freedom worsens community, health, life satisfaction and work-life balance in Russia because of its low future orientation. For life satisfaction, Poland also faces a negative effect of economic freedom, due to its relative low future orientation, and for health this also applies to some other, relatively short-term oriented, countries. In Switzerland

15 Following a suggestion of a reviewer, we performed robustness analysis dropping control variables the effects of which have doubtful signs (for political rights, net Gini coefficient, and great circle air distance). We found that the interaction effect is robust in all six cases. Also the positive effects of economic freedom are robust (as well as its negative effect on work-life balance). However, the positive linear effect of longterm orientation disappears in two out of four cases. 


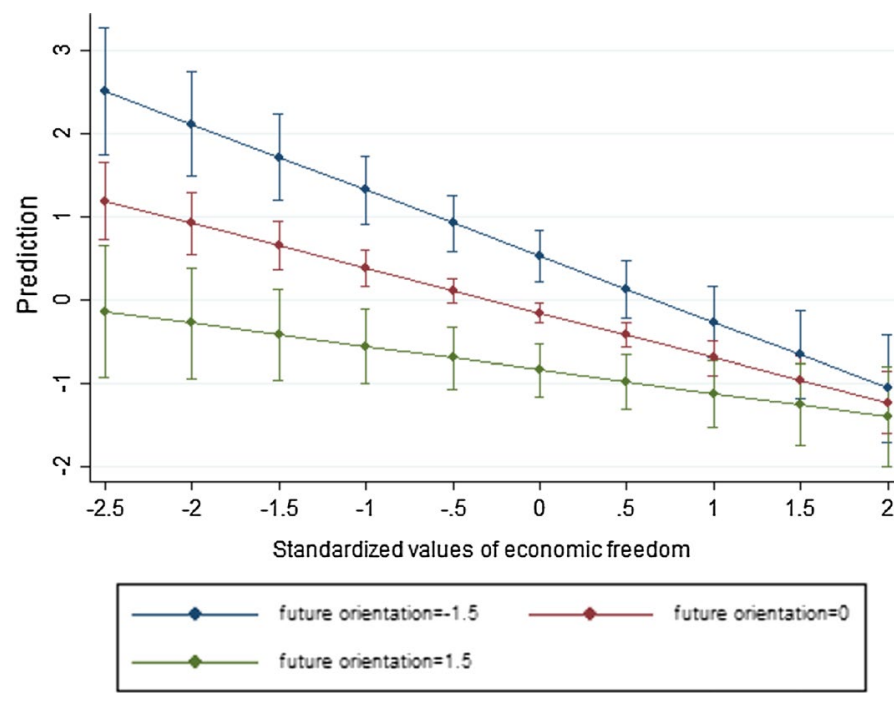

Fig. 3 Standardized effect of economic freedom on work-life balance with $95 \%$ confidence interval

an increase in economic freedom improves all well-being dimensions of the OECD better life index, except for work-life balance where the total effect of economic freedom is still negative, although strongly diminished. The table unambiguously shows the importance of future orientation on the impact of economic freedom on well being.

Figure 2 provides an indication of the significance of the effect of economic freedom on well-being across different levels of economic freedom and future orientation by plotting the standardized effects of economic freedom on income for three different levels of future orientation that fit the range of values in our sample.

If future orientation is low (blue line), income is hardly affected by economic freedom, as the positive linear effect is largely compensated by a negative interaction effect. For countries with medium future orientation (red line), economic freedom affects income only through the positive linear effect. For all values of economic freedom, this effect is significant. If future orientation is high, the effect of economic freedom on income further increases, as the linear effect is enforced by a positive interaction effect.

Figure 3 depicts the negative marginal effect of economic freedom on work-life balance, again for three types of countries with low, medium and high future orientation. In all cases, economic freedom has a negative effect on work-life balance, but the marginal effect diminishes with future orientation.

\section{Conclusions}

This paper studies the relationship between economic freedom and 11 dimensions of wellbeing as measured by the OECD Better Life Index and how this relationship is moderated by long-term orientation. Our analysis provides evidence of a positive link between economic freedom and most dimensions of well-being. Only for work-life balance do we find a negative relationship with economic freedom, whereas for community the effect is 
insignificant. These findings are in line with explorative research by Nikolaev (2014). But whereas Nikolaev (2014) only used bivariate correlation analysis for 1 year, our results provide more robust evidence by using a period of 7 years instead of 1 year and controlling for more control variables.

The most important contribution of this paper to the literature concerns testing the novel hypothesis that the relationship between economic freedom and well-being is contingent on long-term orientation. For six out of the 11 dimensions of well-being measured by the OECD, we find that long-term orientation moderates the relationship between economic freedom and well-being. These results indicate that economic freedom is particularly related to well-being in a cultural environment where people and companies exhibit virtues such as self-command, temperance, patience, perseverance, and foresight (prudence) that enable them to engage in future-oriented behaviors such as planning, investing in the future, and delaying individual or collective gratification. Although we should be careful in interpreting our results as evidence of causality, these results indicate that long-term orientation may be a necessary condition for economic freedom to increase those well-being aspects that require long-term investment, such as economic growth through innovation, health and safety. People who are long-term oriented will also show restraint when market incentives seduce them to work so hard that the balance between work and private life is distorted. Long-term orientation helps them preserve the right balance between working and leisure, so that they can work in a way that is sustainable and satisfying. In the case of work-life balance, long-term orientation thus diminishes the negative effects of economic freedom on leisure.

For four of the five other dimensions of well-being, we find that the positive relationships of long-term orientation and economic freedom with well-being are not interrelated. These findings suggest that the relationship between economic freedom and well-being is not always contingent on long-term orientation, and that a stronger long-term orientation can go together with higher well-being even if economic freedom is low. Similarly, more economic freedom will be associated with higher well-being even in the presence of weak long-term orientation. A possible explanation is that these dimensions of well-being (particularly education, environment, and civic engagement) may be relatively more dependent on government policies, and that governments may also be more long-term oriented in a society where long-term orientation prevails. In that case the effect of a change in longterm orientation on well-being will be independent of the level of economic freedom.

For housing, we find no effect of long-term orientation or the interaction term with economic freedom. This is in contrast to the bivariate correlation analysis that shows that housing and long-term orientation are positively related. This positive relationship disappears once we control for various control variables (particularly the dummy for post-communist countries and female labor market participation). As no previous research has been done into the relationship between long-term orientation and housing, it is difficult to interpret this finding.

Concluding, our study suggests that research into international differences in well-being should not only look at formal institutions or culture in isolation, but also specifically at the interaction between both types of factors. For comparative international research in well-being to make progress it is not only important to better distinguish (formal) institutions from culture, and analyze how these two sets of factors are mutually related, but also to explore more broadly how culture and institutions together, rather than separately, are related to well-being. Besides moderation models, future research should also consider mediation models that explicates the endogeneity of regulative institutions and culture. For example, long-term orientation may be causally dependent on economic freedom, as 
economic freedom may provide incentives for individuals to make long-term investments and plan for the future. Another relevant opportunity for future research is to distinguish between different dimensions of economic freedom to examine potential heterogeneous institutional effects on well-being (Graafland and Compen 2015; Graafland and Lous 2018). Furthermore, the focus on OECD countries reduces the heterogeneity between the countries studied. This limits the generalizability of the findings of the study. When more data would become available in the future, the robustness of the findings of our study should therefore be tested for a broader set of countries and time spans.

Acknowledgements This work was supported by the Templeton World Charity Foundation, Inc. Templeton World Charity Foundation had no involvement in the study design; collection, analysis and interpretation of data; in the writing of the report; and in the decision to submit the article for publication. The author thanks Ghea Wahyu Puspita, Kalle Sølvsteen, and Bjorn Lous for their assistance in compiling information and their help in the regression analysis, and Eelke de Jong and Annemiek Schilpzand and two reviewers for their comments on an earlier version of this paper.

Open Access This article is distributed under the terms of the Creative Commons Attribution 4.0 International License (http://creativecommons.org/licenses/by/4.0/), which permits unrestricted use, distribution, and reproduction in any medium, provided you give appropriate credit to the original author(s) and the source, provide a link to the Creative Commons license, and indicate if changes were made.

\section{Appendix 1}

\section{See Table 6.}

It should be noted that for some aspects there is also evidence of opposite effects. For example, Rigobon and Rodrik (2005) found that trade openness reduces income levels, whereas Kagan, Gunningham and Thornton (2003) found that regulation has been directly responsible for the significant reductions in pulp mill pollution. Furthermore, Graafland and Compen (2015) found that small government may lower life satisfaction, whereas Graafland and Lous (2018) found a negative relationship between life satisfaction and small government, free trade and low government regulation. 


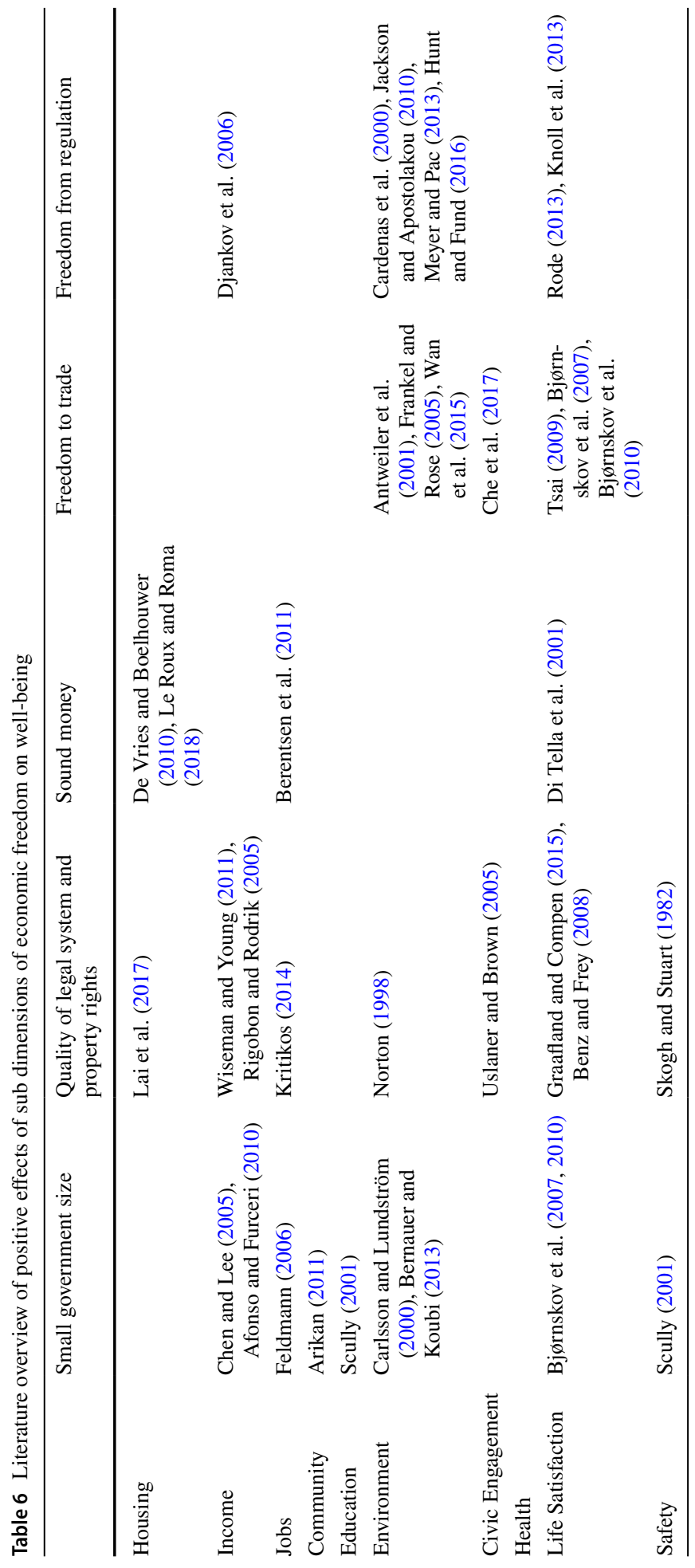




\section{Appendix 2}

\section{See Table 7.}

Table 7 Detailed description of economic freedom index of Fraser Institute Source: http://www.freethewor ld.com/2015/economic-freedom-of-the-world-2015.pdf

\begin{tabular}{|c|c|}
\hline Five areas of economic freedom & Sub indicators \\
\hline Fiscal freedom & $\begin{array}{l}\text { 1. Fiscal freedom (top marginal income rate and } \\
\text { payroll tax rate) } \\
\text { 2. Transfers and subsidies } \\
\text { 3. Government enterprises and investment } \\
\text { 4. Top marginal tax rate }\end{array}$ \\
\hline Legal system and property rights & $\begin{array}{l}\text { 1. Judicial independence } \\
\text { 2. Impartial courts } \\
\text { 3. Protection of property rights, } \\
\text { 4. Military interference in rule of law and politics } \\
\text { 5. Integrity of legal system, } \\
\text { 6. Legal enforcement of contracts } \\
\text { 7. Regulatory costs of the sale of real property } \\
\text { 8. Reliability of police } \\
\text { 9. Business costs of crime }\end{array}$ \\
\hline Access to sound money & $\begin{array}{l}\text { 1. Money growth } \\
\text { 2. Standard deviation of inflation, } \\
\text { 3. Inflation most recent year } \\
\text { 4. Freedom to own foreign currency accounts }\end{array}$ \\
\hline Freedom to trade internationally & $\begin{array}{l}\text { 1. Tariffs } \\
\text { 2. Regulatory barriers } \\
\text { 3. Size of trade sector relative to potential } \\
\text { 4. Black-market exchange rates } \\
\text { 5. Controls of the movement of capital and people }\end{array}$ \\
\hline Freedom from regulation & $\begin{array}{l}\text { 1. Credit market regulations } \\
\text { 2. Labor market regulations } \\
\text { 3. Business regulations }\end{array}$ \\
\hline
\end{tabular}

\section{Appendix 3}

See Table 8. 
Table 8 Countries included in the sample

\begin{tabular}{lllll}
\hline Western Europe & Central Europe & $\begin{array}{l}\text { North America and other } \\
\text { Western countries }\end{array}$ & $\begin{array}{l}\text { Middle and South } \\
\text { America }\end{array}$ & Other \\
\hline Austria & Czech Republic & Canada & Brazil & Israel \\
Denmark & Hungary & United States & Mexico & Japan \\
Finland & Poland & Australia & South Africa \\
France & Russia & New Zealand & South Korea \\
Germany & Slovenia & & Turkey \\
Greece & & & \\
Ireland & & & \\
Italy & & & \\
Netherlands & & & \\
Portugal & & & \\
Spain & & & \\
Sweden & & & \\
Switzerland & & & \\
United Kingdom & & & \\
14 & 5 & & \\
\hline
\end{tabular}

\section{References}

Acemoglu, D., Johnson, S., \& Robinson, J. A. (2001). The colonial origins of comparative development: An empirical investigation. American Economic Review, 91(5), 1369-1401.

Afonso, A., \& Furceri, D. (2010). Government size, composition, volatility and economic growth. European Journal of Political Economy, 26(4), 517-532.

Aixalá, J., \& Fabro, G. (2009). Economic freedom, civil liberties, political rights and growth: A causality analysis. Spanish Economic Review, 11(3), 165-178.

Antweiler, W., Copeland, B. R., \& Taylor, S. M. (2001). Is free trade good for the environment? American Economic Review, 91(4), 877-908.

Arikan, G. (2011). Economic individualism and government spending. World Values Research, 4(3), 73-95.

Balestra, C., Boarini, R., \& Tosetto, E. (2018). What matters most to people? Evidence from the OECD better life index users' responses. Social Indicators Research, 136, 907-930.

Baughn, C. C., Bodie, N. L., \& Mclntosh, J. C. (2007). Corporate social and environmental responsibility in Asian countries and other geographical regions. Corporate Social Responsibility and Environmental Management, 14, 189-205.

Bennett, D. L., Faria, H. J., Gwartney, J. D., \& Morales, D. R. (2017). Economic institutions and comparative economic development: A post-colonial perspective. World Development, 96, 503-519.

Bennett, D. L., \& Nikolaev, B. (2016). Factor endowments, the rule of law and structural inequality. Journal of Institutional Economics, 12(04), 773-795.

Bennett, D., \& Nikolaev, B. (2017). On the ambiguous economic freedom-inequality relationship. Empirical Economics, 53(2), 717-754.

Bennett, D. L., Nikolaev, B., \& Aidt, T. S. (2016). Institutions and well-being. European Journal of Political Economy, 45, 1-10.

Benz, M., \& Frey, B. S. (2008). Being independent is a great thing: Subjective evaluations of selfemployment and hierarchy. Economica, 75, 362-383.

Benzeval, M., \& Judge, K. (2001). Income and health: The time dimension. Social Science and Medicine, 52(9), 1371-1390.

Berentsen, A., Menzio, G., \& Wright, R. (2011). Inflation and unemployment in the long run. American Economic Review, 101, 371-398.

Berggren, N. (1999). Economic freedom and equality: Friends or foes? Public Choice, 100(3-4), 203-223. 
Bernauer, T., \& Koubi, V. (2013). Are bigger governments better providers of public goods? Evidence from air pollution. Public Choice, 156(3-4), 593-609.

Bjørnskov, C., Dreher, A., \& Fischer, J. A. (2007). The bigger the better? Evidence of the effect of government size on life satisfaction around the world. Public Choice, 130(3-4), 267-292.

Bjørnskov, C., Dreher, A., \& Fischer, J. (2008). Cross-country determinants of life satisfaction: Exploring different determinants across groups in society. Social Choice and Welfare, 30(1), 119-173.

Bjørnskov, C., Dreher, A., \& Fischer, J. A. V. (2010). Formal institutions and subjective well-being: Revisiting the cross-country evidence. European Journal of Political Economy, 26, 419-430.

Block, J. H., Millán, A., Millán, J. M., \& Moritz, A. (2018). Entrepreneurship and work-life balance. SSRN: https://ssrn.com/abstract=3148885.

Bozeman, B. (2007). Public values and public interest: Counterbalancing economic individualism. Washington, D.C: Georgetown University Press.

Brammer, S., \& Millington, A. (2008). Does it pay to be different? An analysis of the relationship between corporate social and financial performance. Strategic Management Journal, 29(12), 1325-1343.

Brewer, P., \& Venaik, S. (2010). GLOBE practices and values: A case of diminishing marginal utility? Journal of International Business Studies, 41, 1316-1324.

Bukowski, A., \& Rudnicki, S. (2018). Not only individualism: The effects of long-term orientation and other cultural variables on national innovation success. Cross-Cultural Research. https://doi. org/10.1177/1069397118785546.

Campbell, N. D., Jauregui, A., \& Heriot, K. C. (2008). Housing prices and economic freedom. The Journal of Private Enterprise, 23(2), 1-17.

Cardenas, J. C., Stranlund, J., \& Willis, C. (2000). Local environmental control and institutional crowdingout. World Development, 28(10), 1719-1733.

Carlsson, F., \& Lundström, S. (2000). Political and economic freedom and the environment: The case of $\mathrm{CO}_{2}$ emissions. Working Papers in Economics no 29, University of Gothenburg, Department of Economics.

Che, Y., Lu, Y., Pierce, J. R., Schott, P. K., \& Zhigang, T. (2017). Did trade liberalization with China influence U.S. elections? NBER China, 1-53.

Chen, M. C. (2013). The effect of language on economic behavior: Evidence from savings rates, health behaviors, and retirement assets. American Economic Review, 103(2), 690-731.

Chen, S.-T., \& Lee, C.-C. (2005). Government size and economic growth in Taiwan: A threshold regression approach. Journal of Policy Modeling, 27(9), 1051-1066.

De Haan, J., Lundström, S., \& Sturm, J. E. (2006). Market-oriented policies and economic growth: A critical survey. Journal of Economic Surveys, 20(2), 157-192.

de Vries, P., \& Boelhouwer, P. (2010). House price, house quality and economic growth. European Real Estate Society (ERES). https://doi.org/10.15396/eres2010_392.

Di Tella, R., MacCulloch, R. J., \& Oswald, A. J. (2001). Preferences over inflation and unemployment: Evidence from surveys of happiness. American Economic Review, 91(1), 335-341.

Di Tella, R., MacCulloch, R. J., \& Oswald, A. J. (2003). The macroeconomics of happiness. The Review of Economics and Statistics, 85, 809-827.

Diener, E., \& Suh, E. (1997). Measuring quality of life: Economic, social, and subjective indicators. Social Indicators Research, 40(1-2), 189-216.

Dijk, M., Orsato, R. J., \& Kemp, R. (2013). The emergence of an electric mobility trajectory. Energy Policy, 52(1), 135-145.

Djankov, S., McLiesh, C., \& Ramalho, R. M. (2006). Regulation and Growth. Economics Letters, 92, $395-401$.

Durand, M. (2015). The OECD better life initiative: How' life? And the measurement of well-being. Review of Income and Wealth, 61(1), 4-17.

Faria, H. J., Montesinos-Yufa, H. M., Morales, D. R., \& Navarro, C. E. (2016). Unbundling the roles of human capital and institutions in economic development. European Journal of Political Economy, 45, $108-128$.

Feldmann, H. (2006). Government size and unemployment: Evidence from industrial countries. Public Choice, 127(3-4), 443-459.

Feldmann, H. (2017). Economic freedom and human capital investment. Journal of Institutional Economics, 13(2), 421-445.

Figlio, D., Giuliano, P., Özek, U., \& Sapienza, P. (2016). Long-term orientation and educational performance. NBER Working Paper 22541. http://www.nber.org/papers/w22541.

Frankel, J. A., \& Rose, A. R. (2005). Is trade good or bad for the environment? Sorting out the causality. The Review of Economics and Statistics, 87(1), 85-91. 
Frijters, P., Haisken-DeNew, J. P., \& Shields, M. A. (2005). The causal effect of income on health: Evidence from German reunification. Journal of Health Economics, 24(5), 997-1017.

Galor, O., \& Özak, Ö. (2016). The agricultural origins of time preference. American Economic Review, 106(10), 3064-3103.

Gehring, K. (2013). Who benefits from economic freedom? Unraveling the effect of economic freedom on subjective well-being. World Development, 50, 74-90.

Graafland, J. J., \& Compen, B. (2015). Economic freedom and life satisfaction: Mediation by income per capita and generalized trust. Journal of Happiness Studies, 16(3), 789-810.

Graafland, J., \& Lous, B. (2018). Economic freedom, income inequality and life satisfaction in OECD countries. Journal of Happiness Studies, 19, 2071-2093.

Gropper, D. M., Lawson, R. A., \& Thorne, J. T., Jr. (2011). Economic freedom and happiness. Cato Journal, 31, 237-255.

Guest, D. (2002). Perspective on the study of work life balance. Social Science Information, 41(2), 255-279.

Gwartney, J. (2009). Institutions, economic freedom, and cross-country differences in performance. Southern Economic Journal, 75(4), 937.

Gwartney, J., Hall, J., \& Lawson, R. (2017). Economic freedom of the world: 2017 annual report. Retrieved April 19, 2018, from https://www.fraserinstitute.org/studies/economic-freedom-of-the-world-2017annual-report.

Hall, J. C., \& Lawson, R. A. (2014). Economic freedom of the world: An accounting of the literature. Contemporary Economic Policy, 32, 1-19.

Hartmann, J., \& Uhlenbruck, K. (2015). National institutional antecedents to corporate environmental performance. Journal of World Business, 50, 729-741.

Hofstede, G., Hofstede, G. J., \& Minkov, M. (2010). Cultures and organizations: Software of the mind (Revised and Expanded 3rd Edition ed.). New York: McGraw-Hill.

House, R. J., Hanges, P. J., Javidan, M., Dorfman, P. W., \& Gupta, V. (2004). Culture, leadership, and organizations. The Globe study of 62 societies. Cambridge: Sage Publications.

Hunt, R.A., \& Fund, B.R. (2016). Intergenerational fairness and the crowding out effects of well-intended environmental policies. Journal of Management Studies, 53(5), 878-910.

Inglehart, R., Foa, R., Peterson, C., \& Welzel, C. (2008). Development, freedom, and rising happiness: A global perspective (1981-2007). Perspectives on Psychological Science, 3, 264-285.

Jackson, G., \& Apostolakou, A. (2010). Corporate social responsibility in Western Europe: An institutional mirror or substitute? Journal of Business Ethics, 94, 371-394.

Justesen, M. K. (2008). The effect of economic freedom on growth revisited: New evidence on causality from a panel of countries 1970-1999. European Journal of Political Economy, 24, 642-660.

Kagan, R. A., Gunningham, N., \& Thornton, D. (2003). Explaining corporate environmental performance: How does regulation matter? Law and Society Review, 37(1), 51-90.

Keiser, N.L. (2017). National culture and safety: A meta-analysis of the relationships between Hofstede's cultural value dimensions and workplace safety constructs. Doctoral dissertation, Texas A \& M University.

King, E. M., Montenegro, C. E., \& Orazem, P. F. (2012). Economic freedom, human rights, and the returns to human capital: An evaluation of the Schultz hypothesis. Economic Development and Cultural Change, 61(1), 39-72.

Knoll, B., Pitlik, H., \& Rode, M. (2013). A note on the impact of economic regulation on life satisfaction. Applied Economics Letters, 20(9), 916-920.

Kreps, D. M. (1997). The interaction between norms and economic incentives. Intrinsic motivation and extrinsic incentives. American Economic Review, 87, 359-364.

Kritikos, A.S. (2014). Entrepreneurs and their impact on jobs and economic growth. IZA World of Labour, 1-10. https://wol.iza.org/articles/entrepreneurs-and-their-impact-on-jobs-and-economicgrowth/long

Lai, Y., Zheng, X., Choy, L. H., \& Wang, J. (2017). Property rights and housing prices: An empirical study of small property rights housing in Shenzhen, China. Land Use Policy, 68, 429-437.

Le Roux, J., \& Roma, M. (2018). Recent house price increases and housing affordability. ECB Economic Bulletin, 1, 1-86.

Lewis, S. (2003). The integration of paid work and the rest of life: Is post-industrial work the new leisure? Leisure Study, 22(4), 343-355.

Maitland, I. (1997). Virtuous markets. The market as school of virtues. Business Ethics Quarterly, 7, 17-33.

Mallin, C., Michelon, G., \& Raggi, D. (2013). Monitoring intensity and stakeholders' orientation: How does governance affect social and environmental disclosure? Journal of Business Ethics, 114, $29-43$. 
Mayda, A., \& Rodrik, D. (2005). Why are some people (and countries) more protectionist than others? European Economic Review, 49, 1393-1430.

Mayer, T., \& Zignago, S. (2011) Notes on CEPII's distances measures: The GeoDist Database CEPII Working Paper 2011-25.

McCloskey, D. N. (2006). Bourgeois virtues: Ethics for an age of commerce. Chicago: The University of Chicago Press.

Meyer, A., \& Pac, G. (2013). Environmental performance of state-owned and privatized Eastern European energy utilities. Energy Economics, 36, 205-214.

Milligan, K., Moretti, E., \& Oreopoulos, P. (2004). Does education improve citizenship? Evidence from the U.S. and the U.K. Journal of Public Economics, 88, 1667-1695.

Mizobuchi, H. (2014). Measuring world better life frontier: A composite indicator for OECD better life index. Social Indicators Research, 118, 987-1007.

Murphy, R. H. (2016). Economic freedom of North America at state borders. Journal of Institutional Economics, 12(4), 885-893.

Murphy, R. H., \& O'Reilly, C. (2018). Applying panel vector autoregression to institutions, human capital, and output. Empirical Economics. https://doi.org/10.1007/s00181-018-1562-0.

Nikolaev, B. (2014). Economic freedom and quality of life: Evidence from the OECD's your better life index. Journal of Private Enterprise, 29(3), 61-96.

Nikolaev, B., \& Bennett, D. L. (2016). Give me liberty and give me control: Economic freedom, control perceptions and the paradox of choice. European Journal of Political Economy, 45, 39-52.

Nikolaev, B., \& Bennett, D. L. (2017). Economic freedom and emotional well-being. Journal of Regional Analysis and Policy, 47, 88-99.

Norton, S. W. (1998). Property rights, the environment, and economic well-being. In P. J. Hill \& R. E. Meiners (Eds.), Who owns the environment? (pp. 37-54). Lanham, MD: Rowman \& Littlefield.

Nusbaum, M. (2011). Creating capabilities. Retrieved from http://apps.ufs.ac.za/media/dl/userfiles/ documents/News/2012_12/2012_12_10_Martha_Nussbaum_UFS_December_2012.pdf..

OECD (2000) Literacy in the information age. Final report of the international adult literacy survey. Paris: OECD.

OECD. (2008). Handbook on constructing composite indicators: Methodology and user guide. Paris: OECD Publishing.

Ovaska, T., \& Takashima, R. (2006). Economic policy and the level of self-perceived well-being: An international comparison. Journal of Socio-Economics, 35, 308-325.

Peiró-Palomino, J., \& Picazo-Tadeo, A. J. (2018). OECD: One or many? Ranking countries with a composite well-being indicator. Social Indicators Research, 139(3), 847-869.

Peterson, M. F., Arregle, J. L., \& Martin, X. (2012). Multilevel models in international business research. Journal of International Business Studies, 43(5), 451-457.

Pitlik, H., \& Rode, M. (2016). Free to choose? Economic freedom, relative income, and life control perceptions. International Journal of Wellbeing, 6, 81-100.

Preacher, K. J., Rucker, D. D., \& Hayes, A. F. (2007). Addressing moderated mediation hypotheses: Theory, methods, and prescriptions. Multivariate Behavioral Research, 42(1), 185-227.

Rasmussen, D. C. (2006). Does "bettering our condition" really make us better off? Adam Smith on progress and happiness. The American Political Science Review, 100(3), 309-318.

Reader, T. W., Noort, M. C., Shorrock, S., \& Kirwan, B. (2015). Safety sans frontières: An international safety culture model. Risk Analysis, 35(5), 770-789.

Rehbein, K., Logsdon, J. M., \& Van Buren, H. J., III. (2013). Corporate responses to shareholder activists: Considering the dialogue alternative. Journal of Business Ethics, 112, 137-154.

Reynolds, J., \& Renzulli, L. A. (2005). Economic freedom or self-imposed strife: Work-life conflict, gender, and self-employment. Entrepreneurship, 15, 33-60.

Rigobon, R., \& Rodrik, D. (2005). Rule of law, democracy, openness, and income. The Economics of Transition, 13(3), 533-564.

Rode, M. (2013). Do good institutions make citizens happy, or do happy citizens build better institutions? Journal of Happiness Studies, 14(5), 1479-1505.

Ruseski, J. E., \& Maresova, K. (2014). Economic freedom, sport policy, and individual participation in physical activity: An international comparison. Contemporary Economic Policy, 32(1), 42-55.

Schofer, E., \& Meyer, J. W. (2005). The worldwide expansion of higher education in the twentieth century. American Sociological Review, 70(6), 898-920.

Schor, J. B. (1993). The overworked American: The unexpected decline of leisure. New York: Basic Books.

Scully, G. W. (2001). Government expenditure and well-being. Public Choice, 108(1-2), 123-145.

Sen, A. K. (1984). Resources, values and development. Oxford: Blackwell. 
Skogh, G., \& Stuart, C. (1982). A contractarian theory of property rights and crime. The Scandinavian Journal of Economics, 84(1), 27-40.

Smith, A. (1776) Inquiry into the nature and causes of the wealth of nations. In Campbell, R.H., Skinner, A.S. (eds) Glasgow edition of the works and correspondence of Adam Smith. Indianapolis: Liberty Fund.

Spruk, R., \& Kešeljević, A. (2018). Economic freedom and growth across German districts. Journal of Institutional Economics, 14(4), 739-765.

Stiglitz, J., Sen, A., \& Fitoussi, J. P. (2009). The measurement of economic performance and social progress revisited: Reflection and Overview (pp. 1-65). Paris: Commission on the Measurement of Economic Performance and Social Progress.

Stroup, R.L. (2003). Economic freedom and environmental quality. In Proceedings, federal reserve bank of dallas (pp. 73-90).

Stroup, M. D. (2007). Economic freedom, democracy, and the quality of life. World Development, 35(1), $52-66$.

Tsai, M. C. (2009). Market openness, transition economies and subjective wellbeing. Journal of Happiness, $10,523-539$.

Uslaner, E. M., \& Brown, M. (2005). Inequality, trust, and civic engagement. American Politics Research, 33(6), 868-894.

Van den Berg, J. C. (2009). The GDP paradox. Journal of Economic Psychology, 30(2), 117-135.

Veenhoven, R. (2000). Freedom and happiness. In E. Diener \& E. M. Suh (Eds.), Culture and subjective wellbeing (pp. 257-288). Boston: MIT Press.

Wan, J., Baylis, K., \& Mulder, P. (2015). Trade-facilitated technology spillovers in energy productivity convergence processes across EU countries. Energy Economics, 48, 253-264.

White, M., Hill, S., McGovern, P., Mills, C., \& Smeaton, D. (2003). High-performance management practices, working hours and work-life balance. British Journal of Industrial Relations, 41(2), 175-195.

Wiklund, J., Nikolaev, B., Shir, N., Foo, M.-D., \& Bradley, S. (2019). Entrepreneurship and well-being: Past, present, and future. Journal of Business Venturing. https://doi.org/10.1016/j.jbusvent.2019.01.002.

Wiseman, T., \& Young, A. T. (2011). Economic freedom, entrepreneurship, \& income levels: Some US state-level empirics. American Journal of Entrepreneurship, SSRN: https://ssrn.com/abstract=18178 46.

Publisher's Note Springer Nature remains neutral with regard to jurisdictional claims in published maps and institutional affiliations. 